\title{
21st Century Reading Strategy Program to Read English Reading Material for Primary School Pupils
}

\author{
Suher Sulaiman, Maslawati Mohamad*, Azlina Abdul Aziz, Khairul Farhah Khairuddin, \\ Azlin Norhaini Mansor, Bity Salwana Alias
}

Faculty of Education, Universiti Kebangsaan Malaysia, Bangi, Malaysia

Email: *maslawati@ukm.edu.my

How to cite this paper: Sulaiman, S., Mohamad, M., Aziz, A. A., Khairuddin, K. F., Mansor, A. N., \& Alias, B. S. (2020). 21st Century Reading Strategy Program to Read English Reading Material for Primary School Pupils. Creative Education, 11, 1289-1298. https://doi.org/10.4236/ce.2020.118095

Received: June 20, 2020

Accepted: August 11, 2020

Published: August 14, 2020

Copyright (c) 2020 by author(s) and Scientific Research Publishing Inc. This work is licensed under the Creative Commons Attribution International License (CC BY 4.0).

http://creativecommons.org/licenses/by/4.0/

\begin{abstract}
This paper provides a literature review on reading definitions, issues and challenges of reading English materials at primary level, parents' roles in instilling reading habits among pupils and measures that could be employed to equip the pupils with relevant strategies and knowledge in reading hypermedia reading materials. Reading in Malaysia is not a habitual action. The problem starts even at the early stage of education when the pupils are in primary school. Thus, they need to change their perception of reading. They must also change their reading strategies in accordance with the current trend of reading via websites and the internet and various applications via online. If they cannot cope with the English Language, they cannot read the English reading materials, thus, reading will not be their favorite habit. Parents' role is also one of the important factors to change the children's reading habits. Parents need to be equipped with knowledge so they can lead their children. Hopefully, with various approaches and workshops on reading, the pupils will be ready to change their reading habits. In this conceptual paper, a number of mobile applications will be introduced towards the primary school pupils to gather their attention and equip them with effective hypermedia reading strategies. Furthermore, in this 21st Century Learning, applications and gadgets are relevant to their interest. Parents, community, and the pupils themselves need to familiarize themselves with new applications to promote reading activities and develop a better understanding of reading materials.
\end{abstract}

\section{Keywords}

21st Century, Reading, Primary School, Programs, Reading Materials, English 


\section{Introduction}

Reading is essential for everybody, especially in the 21st century. People will need to read an email, text, or messages from the phone, referring to the grocery list or for the simplest act of all, ordering food from the menu. If they cannot read, they have to ask someone to read for them. Only $12 \%$ of the people in the world could read and write in 1820, and today the figure has reversed: only $14 \%$ of the world population, in 2016, remained illiterate. Over the last 65 years, the global literacy rate has increased by $4 \%$ every 5 years-from $42 \%$ in 1960 to $86 \%$ in 2015 (Roser \& Ortiz, 2020). Roser and Ortiz added, despite large improvements in the expansion of basic education, and the continuous reduction of education inequalities, there are substantial challenges ahead. The poorest countries in the world, where basic education is most likely to be a binding constraint for development, still have exceptionally large segments of the population who are illiterate. While developed countries show a significant increase in literacy, some countries in Africa show slow progress due to poverty and limited access to education. The comparison is to show how poverty may contribute to the percentage of literacy globally. The Malaysian context provides a particularly interesting case study because of the rapid increase in the availability of technology which is enabling access to the various hypermedia reading materials. Yet, there is limited evidence to guide practice.

The positive attitude of reading behavior must be instilled at an early age. It is the parents' and community responsibility on how to attract them to love reading and allow the children to read as much as they could. Regardless of the teachers' effort, pupils themselves also play an important role to develop good reading habits. If their attitude towards reading is just for the sake of completing their academic assignments, then all the well planned reading programs, all the campaigns and promotions towards pleasure reading will be less effective. Furthermore, the pupils nowadays, known as Z Generation, prefer to play online games, attached to the handphone and its applications. Their interests are more on gadgets than in books. There is a rise of a new generation that is "location-aware" and speaks a "technological-language". This has great impacts on the teaching-learning environment as the current pupils are more equipped with technology-related knowledge than typical Generation X (teachers), which increased complexity of the education process involving instruction, guidance, and supervision (Cilliers, 2017).

Many pupils perceived that physical books make them sleepy and bored because they could not interact via two-way communication with the reading materials. Therefore, interactive books make them happy. As Glassner (2017) highlighted, the combination of storytelling and gaming has all the qualities of a great story or game. Parents, pupils, and the community should develop a paradigm shift to promote reading via the internet due to the 21st Century learning environment. This change is widely spread globally, and we should embrace it.

Therefore, measures need to be taken to ensure the pupils change their atti- 
tude towards reading English materials. With the help of technology and various online applications, hopefully, the change is permanent. Malaysians need to read extensively and it will only happen with the constant and vigorous effort from the parents, community, and pupils. Therefore 21st reading strategy programs to read English reading materials will be a small step for primary school pupils to transform their mindset into new perceptions towards reading in English and make reading as a habit.

This paper includes the literature review on pupils' literacy, and reading habits among pupils in Malaysia. After that, the literature review covers the issues and challenges faced by pupils. After identifying the issues and challenges, measures to tackle them are then discussed particularly on mobile learning. Later, this paper includes the literature review on parents' roles. Parents should play their roles in instilling their children with a positive attitude and reading habits.

\section{Pupils' Literacy}

When elementary school children struggle with reading, teachers and parents are worried. When young children are reluctant to even engage in the act of reading, the situation becomes more worrisome. The words and phrases describe these children's attitudes as reluctant, disengaged, unmotivated, falling behind, at-risk. A growing number of students are wearing these labels at schools (Bright, 2017). He added, from kindergarten to the first grade, the foundation of basic literacy is supposed to be laid as a larger access skill for nearly every area to follow. "Reading difficulty is a particularly salient marker for achievement in young children because it is a primary focus of early education and a principal predictor of current and later achievement" (Grills-Taquechel, Fletcher, Vaughn, \& Stuebing, 2012: p. 36). Low proficiency and low confidence in using the English Language resulted in the primary pupils' fear to read in English. Moreover, they become a laughing stock among their peers when they mispronounce some words when they are asked to read aloud reading texts in their English lesson. As a result, their self-esteem could be adversely affected.

\section{Reading Habit among Pupils in Malaysia}

In 2018, the adult literacy rate in Malaysia was $94.9 \%$. The adult literacy rate has increased from $82.9 \%$ in 1991 to $94.9 \%$ in 2018, growing at an average annual rate of 2.30\% (World Data Atlas, 2018). The numbers indicate that the majority of Malaysians could read. The ability to read starts from pre-school or earlier and it continues throughout one's lifetime. However, in 2014, Malaysians, on average, read about 15 books a year based on a study conducted by the National Library. However, this is still a long way to go compared to those from developed countries who read an average of 40 books a year (Meikeng, 2019). 53\% of Malaysian students could not meet the minimum proficiency level in international Reading Tests. Based on the results released by the Organization for Economic Cooperation and Development (OECD), in 2018, Malaysia scored 415 in 
Reading literacy in Program for International Students Assessments (PISA) (Chin, 2019). The results are as in Figure 1 and Figure 2.

It is compulsory for the pupils to be involved in NILAM (Nadi Ilmu Amalan Membaca) or as known as "Reading is the Heart of Knowledge" Program (Preschool to Year Six). Then, this program continues from Form 1 until Form 5 in Secondary School. The implementation of this program indicates that the Malaysian Government takes reading as a serious matter Under NILAM program, primary and secondary school pupils must read a certain number of books or reading materials. After achieving a certain number of books, they will be awarded with stars. Refer to Table 1 for the indicators.

Based on Table 1, pupils must read extensively to get rewarded by a star or

\section{Snapshot of performance trends in MALAYSIA}

\begin{tabular}{|c|c|}
\hline PISA 2000 & $\mathrm{~m}$ \\
\hline PISA 2003 & $\mathrm{~m}$ \\
\hline PISA 2006 & $\mathrm{~m}$ \\
\hline PISA 2009 & 414 \\
\hline PISA 2012 & $398^{*}$ \\
\hline PISA 2015 & m \\
\hline PISA 2018 & 415 \\
\hline Average 3-year trend in mean performance & +2.2 \\
\hline Short-term change in mean performance (2015-2018) & M \\
\hline Overall performance trajectory & stable \\
\hline Proficiency levels & $\begin{array}{c}\text { Reading } \\
\text { (2009 to 2018) }\end{array}$ \\
\hline Percentage-point change in top-performing students (Level 5 or 6 ) & +0.4 \\
\hline Percentage-point change in low-performing students (below Level 2) & +1.9 \\
\hline Variation in performance & $\begin{array}{c}\text { Reading } \\
\text { (2009 to 2018) }\end{array}$ \\
\hline Average trend amongst the highest-achieving students ( $90^{\text {th }}$ percentile) & $+5.6^{*}$ \\
\hline Average trend amongst the lowest-achieving students ( $10^{\text {th }}$ percentile) & +1.1 \\
\hline Gap in learning outcomes between highest- and lowest-achieving students & Stable gap \\
\hline \multicolumn{2}{|c|}{$\begin{array}{l}\text { *indicates statistically significant trends and changes, or mean-performance estimates that are } \\
\text { significantly above or below PISA } 2018 \text { estimates. } \\
\text { Source: OECD, PISA } 2018 \text { Database, Tables I.B1.7-I.B1.15 and I.B1.28-I.B1.30. }\end{array}$} \\
\hline
\end{tabular}

Figure 1. Malaysia's reading literacy in PISA 2018.

Mean score in Programme for International Student Assessment 2018

Mainland China Reading!

Singapore

Macau

Hong Kong

Taiwan

Malaysia

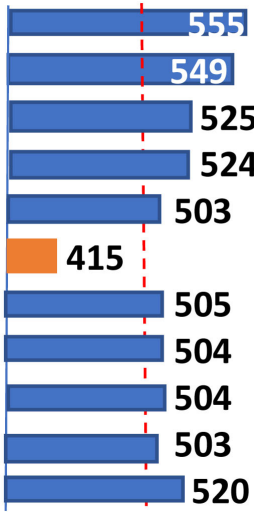

US

Britain

Japan

Australia

Canada

OECD average 487

Source: Organisation for Economic Co-operation and Development

Figure 2. Malaysia reading score amongst other countries in PISA 2018. 
Table 1. NILAM program reward chart.

\begin{tabular}{|c|c|c|c|c|c|c|c|}
\hline \multirow{6}{*}{ 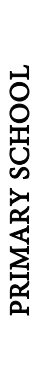 } & \multirow{2}{*}{$\begin{array}{c}\text { Reward } \\
1 \times\end{array}$} & \multicolumn{2}{|c|}{$\begin{array}{c}\text { Number of Reading } \\
\text { Materials }\end{array}$} & \multirow{6}{*}{ 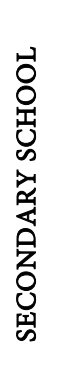 } & \multirow{2}{*}{$\begin{array}{c}\text { Reward } \\
1 \times\end{array}$} & \multicolumn{2}{|c|}{$\begin{array}{c}\text { Number of Reading } \\
\text { Materials }\end{array}$} \\
\hline & & 144 & 287 & & & 120 & 239 \\
\hline & $2 x$ & 288 & 431 & & $2 *$ & 240 & 359 \\
\hline & $3 x$ & 432 & 575 & & $3 x$ & 360 & 479 \\
\hline & $4 \times$ & 576 & 719 & & $4 \times$ & 480 & 599 \\
\hline & $5 *$ & 720 & and more & & $5 *$ & 600 & and more \\
\hline
\end{tabular}

two. It is doubtful for them to achieve the school aim based on the current reading habit among pupils. As mentioned earlier, the attitude towards reading plays an important role for the pupils to change their reading habits.

\section{Issues and Measures to Tackle the Issues}

In general, the issues faced by pupils in reading could be divided into socioeconomic factors, school equipment, and pupils' commitment.

\subsection{Family Income}

The socioeconomically disadvantaged schools with low ESCS mean outperformed the socioeconomically disadvantaged students from school with high ESCS mean in PISA 2009+ and PISA 2012 (Thien, 2016). The financial standing of a family plays an important role in pupils' academic performance. For example, parents with better socioeconomic ability could afford to buy books or to pay for the tuition classes (Mohamad \& Zakaria, 2018). Their findings also indicate that extensive reading and sufficient assistance when pupils face difficulties in reading could help them to become more effective readers.

However, many pupils from poor families could also excel in their academic performance if the pupils possess high motivation to succeed and strive to excel constantly. Therefore, the people around them such as parents, community and teachers play important roles to ensure that the pupils are motivated to read.

Low proficiency and low confidence in using the English Language resulted in the primary pupils' fear to read in English. Moreover, when they become a laughingstock among their peers when they mispronounce some words, slowly, their self-esteem vanishes... The Internet is the encyclopedia of information related to every topic of the world. It is a medium for getting information about the world (Blair-Larsen \& Vallance, 2004). When browsing for information via the internet, reading skills are necessary to read materials in English.

\subsection{School Facilities}

For many students, especially those from low income family, they depend much on school facilities for books and internet accessibility. School facilities help the pupils to develop the ability to read and write. For example, netbooks, websites, and books in the library. 
Teachers and school administrators need to know how to arrange and use the facilities wisely. For less equipped schools-with no internet line, no netbook to use, or only 2 or 3 computers, they have to think of alternatives to make teaching and learning more meaningful and exciting. Teachers could use recycled products, and equipment available in the school. Teachers could also get the members of the Parents and Teachers Association (PTA) to find solutions on how to overcome the problems of limited financial resources in order to pay for the internet and purchase other facilities.

\subsection{Pupils' Commitment}

There is no secret how most pupils behave in school and at home. Under their parents' observation, they can do chores, for example, washing dishes, watering plants, or taking out the rubbish. They can even read with adult supervision. However, when the parents are not around, they tend to play online games, watching YouTube or television, or even sleep at their ease. They need to be reminded and monitored constantly to do their reading.

A timetable would be one of the best ways to solve this problem. They will obey the schedule or roster accordingly. Well, no doubt they are quite devious and cunning, but, with the discipline, it can be done successfully.

\subsection{Parents' Roles}

Reading is also necessary to satisfy one's thirst for knowledge. However, in Malaysia, many books are written in English. Undoubtedly, the importance of reading in English is a global awareness because it is a major language that we need to learn and master. Parents play an important role to make reading activities successful. As mentioned earlier, they could show a good example by being a role model for their children. Parents should read together with their children, buy suitable books according to their children's level of interest, and make sure they spend enough time to read every day in order to make them proficient readers. Currently, as most parents are working, the time spend with their children is limited. Most of the time, their children do their reading to complete their schoolwork. They perceive reading as a chore, not a pleasurable activity.

In Malaysia, English is not our National Language, but it is a second language. English is taught as a compulsory subject from primary school until the tertiary level. Most of the references at tertiary institutions are written in English thus the pupils need to be equipped with reading strategies to read in English. Reading for pleasure has influenced pupils' academic performance. The parental role is pivotal in developing children's interest in reading because healthy reading activities can help them to also develop critical thinking and analytic skills. Reading for pleasure could also develop their vocabulary to a great extent. Consequently, children exhibit improvement in their overall academic performance (Bano, Jabeen, \& Qutoshi, 2018). Findings also indicate that parents who focused on putting efforts to improve reading interest and habit of their children at an 
early age could better develop the reading habit as the children's routine activity (Bano, Jabeen, \& Qutoshi, 2018). Li, Nan, Xu, and Li (2020) findings indicate a significant positive correlation between the frequency of parent-child literacy activities and children's perceptions of the quality of the parent-child relationship.

\section{Reading Program}

It is known that parents' involvement contributes to children's overall educational achievement as well as their literacy development. Home literacy, in particular, is critical in helping children who read below grade level. Studies also prove that quality interaction between the child and parent is important (Brown, Schell, Denton, \& Knode, 2019). No doubt parents play a crucial part to make reading as part of their favorite pastime. As a role model, children tend to follow their parents in many aspects. When they read together, it will show a good example for their children to make it a part of their habit. Reading habits need to be nurtured from time to time. Parents have the authority to mold their children according to their preferences. This will affect their future generation and hopefully will make their children love reading. Brown et al., 2019, added, educators encouraged all parents to be involved in literacy practices at home, but special care is necessary when working with English Language (EL). Some parents may not believe they can contribute to their children's reading success because of their own EL low proficiency status and unfamiliarity with literacy practices. In Malaysia, fluent EL parents mainly cluttered in the urban area or/and the outskirts of the city, and seldom to be found in the rural areas, but, parents in the rural areas could still have reading activities as their family practices.

The reading programs should expose the parents to relevant reading strategies and how to select appropriate reading materials for their children. Among the relevant reading strategies are on how to develop connections with extratextual materials, such as materials relating to oneself, other texts, and other people (Hamdan, Mohamad, \& Shaharuddin, 2017). Cognitive strategies such as inferential thinking, intertextuality, monitoring comprehension, and evaluation are deeply linked to sociocultural reading strategies such as connection to self and socio-affective strategies. For example, making inferences using their background knowledge can develop their critical analysis of a text. This reading strategy mainly focuses on relating their new knowledge with their former knowledge gained from their experiences. For example, when they stumbled upon a word in English (i.e. huge) the parents should guide the pupils through their experience or memory about the object related to the word 'huge'. Through this technique, pupils can relate the words they do not know in English and attempt to find the solutions to know the words' meaning. It helps the pupils to make reading more interesting and meaningful and will continue reading the book. The reading strategies employed by good and poor language learners varied. Good language learners tend to use more effective strategies while poor language learners employ more compensation strategies (Ling \& Yamat, 2020).

The following are some measures that could be employed by parents, com- 
munity and teachers in order to develop effective readers among Malaysian pupils.

\section{Measures to Improve Reading Ability}

Some of the proposed measures are:

1) introducing mobile learning

2) organizing reading English materials workshop

3) organizing reading competitions

4) organizing hands-on workshop for parents and community

\subsection{Introducing Mobile Learning}

The studies on mobile usage indicate that youth tend to be more attached to mobile applications than older people. Mobile learning is the process of learning that can be done anywhere at any time by using mobile technologies and the internet (Masrom, Nadzari, \& Zakaria, 2016). Mobile learning is obviously not merely a combination of "mobile" and "learning". There is no standard definition of mobile learning as many authors and researchers have given various definitions. However, to simplify the definition, mobile learning or " $m$-learning" is defined as the subset of "e-learning" while "e-learning" is the subset of distance learning. It is a type of distance education that focuses on learning across context and learning with mobile devices. In addition, "m-learning" is the ability to use mobile devices to support teaching and learning (Masrom, Nadzari, Mahmood, Zakaria, \& Ali, 2016).

There are many benefits of mobile learning. First, mobile learning could eliminate geographical boundaries (Masrom, Nadzari, Mahmood, Zakaria, \& Ali, 2016). Second, mobile learning could provide a collaborative learning environment among groups, locally and globally. Third, the Internet is the encyclopedia of information related to every topic of the world. It is a medium for getting information about the world (Blair-Larsen \& Vallance, 2004).

Due to the various benefits of mobile learning, it should be implemented in Malaysia to assist and improve the learning process. However, when browsing for information via the internet, reading skills are necessary to read materials in English. Therefore, it is essential to equip pupils since primary schools with mobile reading strategies to help them become effective readers, especially in reading English reading materials.

The mobile applications workshop should be held via hands-on to ensure the pupils completely understand the functions and the usage of the app. They need to be shown and guided on how to install the apps, and how to use them (Noor Diana, Maslawati, Wee, \& Melor, 2018). They also recommend that facilitators can be appointed from the school teachers or personnel who use the apps frequently.

\subsection{Organizing Reading English Materials Workshop}

Reading workshops can be carried out not necessarily in schools. For example, it 
can be done in tournaments like fishing tournaments, football tournaments, and family days. The content of the workshop should include how to develop good reading strategies based on their reading abilities and where to find the reading materials. Active participation from various parties is needed to make sure the workshops are interesting and beneficial for the pupils.

\subsection{Organizing Reading Competitions}

This competition can be held at schools or mass gatherings to attract them to reading books. The competition should be based on the children's reading fluency, intonation and pronunciation, and the technical part of reading. This competition is suitable to be held among schools at the district level. They can have fair experience in reading and moreover will gain knowledge of the reading activities conducted by other schools.

\subsection{Organizing Hands-On Workshop for Parents and Community}

The parents and community participation in such programs are very essential. They can equip themselves with appropriate knowledge and later can guide the pupils in reading. The workshop can be held at school and conducted by the teachers or other bodies to encourage participation from the children's parents and community.

\section{Conclusion}

Clearly, parents, teachers, and community play an important role to help pupils to read fluently and proficiently. No doubt with the help of various parties, it will enhance the pupils' reading ability and performance. Teachers need to work beyond classroom activities to ensure the success of this program. The parents should monitor their children's progress at home and give feedback to the school. Pupils need to give their full commitment towards this program and the results will show after a month or two if they follow the instructions closely. All and all, the reading programs will be a great success if all the parties are willing to work hand in hand.

\section{Conflicts of Interest}

The authors declare no conflicts of interest regarding the publication of this paper.

\section{References}

Bano, J., Jabeen, Z., \& Qutoshi, S. B. (2018). Perceptions of Teachers about the Role of Parents in Developing Reading Habits of Children to Improve their Academic Performance in Schools. Journal of Education and Educational Development, 5, 42-59. https://doi.org/10.22555/joeed.v5i1.1445

Blair-Larsen, S. M., \& Vallance, K. M. (2004). Comprehension Instruction in a Balanced Reading Classroom. In The Balanced Reading Program: Helping All Students Achieve Success (pp. 37-52). 
Bright, A. (2017). Improving Reading with Targeted Strategies for a Reluctant Elementary Reader. Journal of Teacher Action Research, 3, 1-18.

Brown, C. L., Schell, R., Denton, R., \& Knode, E. (2019). Family Literacy Coaching: Partnering with Parents for Reading Success. School Community Journal, 29, 63-86.

Chin, C. (2019). Malaysia Improves in PISA Performance. The Star, 1-2.

Cilliers, E. J. (2017). The Challenge of Teaching Generation Z. PEOPLE: International Journal of Social Sciences, 3, 188-198. https://doi.org/10.20319/pijss.2017.31.188198

Glassner, A. (2017). Interactive Storytelling: Techniques for 21st Century Fiction. Boca Raton, FL: CRC Press. https://doi.org/10.1201/9780429259043

Grills-Taquechel, A. E., Fletcher, J. M., Vaughn, S. R., \& Stuebing, K. K. (2012). Anxiety and Reading Difficulties in Early Elementary School: Evidence for Unidirectional- or Bi-Directional Relations? Child Psychiatry and Human Development, 43, 35-47. https://doi.org/10.1007/s10578-011-0246-1

Hamdan, N. A., Mohamad, M., \& Shaharuddin, S. (2017). Hypermedia Reading Materials: Undergraduate Perceptions and Features Affecting Their Reading Comprehension. The Electronic Journal of e-Learning, 15, 116-125.

Li, S., Nan, N., Xu, Q., \& Li, J. (2020). Perceived Quality of Parent-Child Relationships by Chinese Primary School Students: The Role of Parents' Education and Parent-Child Literacy Activities. Child Language Teaching and Therapy, 0265659020915943. https://doi.org/10.1177/0265659020915943

Ling, C. K. S., \& Yamat, H. (2020). Reading Strategy Use among Good and Poor Primary English as a Second Language Learners. International Journal of Academic Research in Business and Social Sciences, 10, 318-330. https://doi.org/10.6007/IJARBSS/v10-i1/6853

Masrom, M., Nadzari, A. S., \& Zakaria, S. A. (2016). Implementation of Mobile Learning Apps in Malaysia Higher Education Institutions. In E-Proceeding of the 4th Global Summit on Education (pp. 268-276).

Masrom, M., Nadzari, A. S., Mahmood, N. H. N., Zakaria, W. N. W., \& Ali, N. R. M. (2016). Mobile Learning in Malaysia Education Institutions. Issues in Information Systems, 17, 152-157.

Meikeng, Y. (2019). Malaysian Love Reading, But Fewer Local Books Sold. The Star, 1-2.

Mohamad, M., \& Zakaria, N. Y. K. (2018). Development of English Language Camp Module: Reception and Perception of Asnaf Pupils in Malaysia. Global Journal Al-Thaqafah, 8, 31-44.

Noor Diana, S., Maslawati, M., Wee, W. N., \& Melor, M. Y. (2018). Writing the WhatsApp Way!. International Journal of Innovative Research and Creative Technology, 4.

Roser, M., \& Ortiz-Ospina, E. (2020). Literacy. https://ourworldindata.org/literacy

Thien, L. M. (2016). Malaysian Students' Performance in Mathematics Literacy in PISA from Gender and Socioeconomic Status Perspectives. The Asia-Pacific Education Researcher, 25, 657-666. https://doi.org/10.1007/s40299-016-0295-0

World Data Atlas (2018). Malaysia Adult (15+) Literacy Rate. https://knoema.com/atlas/Malaysia/topics/Education/Literacy/Adult-literacy-rate 